RKCL4789

\title{
PREPARATION, CHARACTERIZATION, ACTIVITY AND \\ SELECTIVITY OF HIGHLY LOADED OXIDE PROMOTED \\ RUTHENIUM CATALYSTS FOR SELECTIVE HYDROGENATION OF BENZENE TO CYCLOHEXENE
}

Lucio Ronchin, Andrea Vavasori and Luigi Toniolo*

Department of Chemistry, University of Venice, Dorsoduro 2137, 30123 Venezia, Italy

Received May 18, 2005

Accepted July 15, 2005

\begin{abstract}
The influence of promoters and precipitants of the catalyst precursor on the activity and selectivity of the hydrogenation of benzene to cyclohexene catalyzed by highly loaded oxide-promoted $\mathrm{Ru} / \mathrm{ZrO}_{2}$ catalysts, carried out in a tetraphase reactor (in the presence of an aqueous solution of $\mathrm{ZnSO}_{4}$ ), at $423 \mathrm{~K}$ and $5 \mathrm{MPa}$, was studied. The effect of hydrogen diffusion on the reaction kinetics and on the selectivity has been taken into consideration, the internal pore diffusion being actually the limiting step. Hydrogen chemisorption measurements indicate that the catalyst activity is not influenced by the Ru dispersion, but rather by weakly chemisorbed species.
\end{abstract}

Keywords: Benzene selective hydrogenation, cyclohexene, $\mathrm{Ru} / \mathrm{ZrO}_{2}$ catalysts, oxide promoters, weak hydrogen chemisorption

\section{INTRODUCTION}

The selective hydrogenation of benzene to cyclohexene is of much interest because is connected to the synthesis of cyclohexanol, an intermediate for largescale polyamide production. Recently, many researchers have investigated the influence of the reaction conditions on the activity and the selectivity, mainly

*Corresponding author. Tel. +39-041-2348553

E-mail: toniolo@unive.it 
employing unsupported Ru catalysts [1-6]. The best results have been obtained in a tetraphase reactor at $423 \mathrm{~K}$ and $5 \mathrm{MPa}$ of pressure in the presence of an aqueous solution of $\mathrm{ZnSO}_{4}$ and of suspended $\mathrm{ZrO}_{2}$. The latter inhibits the agglomeration of the $\mathrm{Ru}$ particles. $56 \%$ yield and $80 \%$ selectivity have been claimed [4].

The support can also be a promoter for both activity and selectivity [7, 8], as it can affect the hydrophilicity, a key factor for the catalyst selectivity, because water can displace cyclohexene from the $\mathrm{Ru}$ surface thus preventing further hydrogenation to cyclohexane [9-13].

In addition, it has been observed that the selectivity is influenced by the nature of the alkali used for the precipitation of the catalyst precursor [11-13].

This paper deals with the influence of different metal oxide promoters on highly loaded $\mathrm{Ru} / \mathrm{ZrO}_{2}$ catalysts, as well as with the influence of alkali treatment on the activity and selectivity, in relation to their hydrogen chemisorption properties.

\section{EXPERIMENTAL}

\section{Catalyst preparation}

In a typical preparation, $80 \mathrm{~mL}$ of a $5 \%$ aqueous solution (or an aqueous suspension, the bases $\mathrm{M}(\mathrm{OH})_{2}, \mathrm{M}=\mathrm{Ca}, \mathrm{Sr}, \mathrm{Ba}$, are significantly less soluble in water than the others) of the precipitant (metal hydroxide, e.g. $\mathrm{NaOH}$ ) was placed into a flask to which $5 \mathrm{~g}$ of $\mathrm{Zr}(\mathrm{OPr}-i)_{4}$ was quickly added at room temperature. The temperature was then raised to $353 \mathrm{~K}$, the solution of the promoter and that of $\mathrm{RuCl}_{3}$ were added in sequence $(\mathrm{Ru} /$ promoter $=5 / 1$, promoters: $\mathrm{FeCl}_{3}, \mathrm{NiCl}_{2}, \mathrm{CoCl}_{2}, \mathrm{CrCl}_{3}, \mathrm{MnCl}_{2}$ and $\mathrm{V}_{2} \mathrm{O}_{5}$ ). The resulting suspension was left at $353 \mathrm{~K}$ for $3 \mathrm{~h}$ and then cooled to room temperature and maintained at this temperature for $18 \mathrm{~h}$. The solid was then filtered, collected in an autoclave, suspended in water and pressurized with $\mathrm{H}_{2}(5 \mathrm{MPa})$. The reduction was carried out for $7 \mathrm{~h}$ at $423 \mathrm{~K}$. The reactor was then cooled to room temperature and kept overnight (16-18 h) at this temperature. The autoclave was then depressurized, opened and the catalyst was passivated in water with air for one hour. Finally, the passivated catalyst was filtered and dried under vacuum.

\section{Catalyst characterization}

Particle size was determined by measuring the sedimentation rate, average particle diameter of $4 \mu \mathrm{m}$ has been observed.

Catalyst porosity and surface area has been determined by $\mathrm{N}_{2}$ adsorption and 
desorption at $94 \mathrm{~K}$. All catalysts present an average porosity of 0.7 , average pore diameter of $7 \mathrm{~nm}$ and surface area in the range $170-190 \mathrm{~m}^{2} \mathrm{~g}^{-1}$ [14].

Chemisorption of hydrogen were carried by the double isotherm method at $373 \mathrm{~K}$, a final pressure of 200 Torr and $30 \mathrm{~min}$ of equilibration time [12, 13, 15, 16]. Before the measurements, the catalyst was pretreated in order to reduce the exposed $\mathrm{Ru}$ atoms (reduction under $\mathrm{H}_{2}$ at $673 \mathrm{~K}$ for $4 \mathrm{~h}$ and thermal treatment under vacuum at $673 \mathrm{~K}$ for $4 \mathrm{~h}$ ).

The composition of the catalysts was determined by AAS analysis of the dissolved catalysts by a procedure described elsewhere [12, 13].

\section{Hydrogenation of benzene}

The reaction was carried out in a $250 \mathrm{~mL}$ PTFE lined stainless steel autoclave maintained at constant pressure and temperature (typically $5 \mathrm{MPa}$ and $423 \mathrm{~K}$ ). In a typical experiment $120 \mathrm{mg}$ of catalyst, $40 \mathrm{~mL}$ of benzene and $40 \mathrm{~mL}$ of aqueous $0.6 \mathrm{~mol} \mathrm{~L}-1$ solution of $\mathrm{ZnSO}_{4}$ was loaded. The progress of the reaction was followed by GC analyses of samples of the organic phase and by measuring the hydrogen consumption [10-13].

The activity of the catalysts was calculated by fitting the experimental data with a kinetic model based on two consecutive reactions (benzene to cyclohexene and further hydrogenation to cyclohexane) and on a parallel one (direct formation of cyclohexane from benzene), as described elsewhere [11-13].

\section{RESULTS AND DISCUSSION}

\section{Influence of the metals on reaction kinetics and selectivity}

Entries 1-11 in Table 1 show the results obtained with $\mathrm{Ru} / \mathrm{M}_{\mathrm{x}} \mathrm{O}_{\mathrm{y}} / \mathrm{ZrO}_{2}$ catalysts, which are compared with those obtained with $\mathrm{Ru} / \mathrm{ZrO}_{2}$ (entry 12 , [10]). The inspection of the Carberry and Wheeler-Weisz number for hydrogen suggests that kinetics is only partially affected by external diffusion limitation and that also internal diffusion has little influence even in the case of entries 6, 7 and 12 (see Table 1) [14, 15]. The comparison of the initial selectivity to cyclohexene of entries 1-11 with that of entry 12 indicates that in most cases the second metal oxide (slightly) decreases the selectivity except for entry 3 . However, the catalysts promoted with $\mathrm{Fe}$ and precipitated with $\mathrm{NaOH}$ or $\mathrm{KOH}$, which show a selectivity comparable to that obtained with the $\mathrm{Ru} / \mathrm{ZrO}_{2}$ catalyst give a slight increase in the maximum yield. This is because the presence of iron allows a slower decreasing of the selectivity with increasing conversion (see Fig. 1). 
Table 1

Initial rate, selectivity, yield and hydrogen diffusion parameters of $\mathrm{Ru}-\mathrm{M}_{\mathrm{x}} \mathrm{O}_{\mathrm{y}} / \mathrm{ZrO}_{2}$ catalysts

\begin{tabular}{|c|c|c|c|c|c|c|}
\hline Entry & Catalyst ${ }^{\text {a) }}$ & $\begin{array}{c}\mathrm{N}_{\mathrm{Ca}} \\
\mathrm{H}_{2}\end{array}$ & $\begin{array}{c}\eta \phi^{2} \\
\mathrm{H}_{2}\end{array}$ & $\begin{array}{c}\mathrm{r}_{0} \mathrm{H}_{2}{ }^{\mathrm{b})} \\
\left(10^{2} \mathrm{~mol} \mathrm{~L}^{-1}\right. \\
\left.\mathrm{s}^{-1} \mathrm{~g}_{\mathrm{Ru}}{ }^{-1}\right)\end{array}$ & $\begin{array}{l}\text { Initial }^{\mathrm{c})} \\
\text { selectivity } \\
(\%)\end{array}$ & $\begin{array}{c}\text { Maximum } \\
\text { yield } \\
(\%)\end{array}$ \\
\hline 1 & $\mathrm{Ru} / \mathrm{Ni} / \mathrm{ZrO}_{2}-\mathrm{Na}$ & 0.07 & 0.84 & 18 & 57 & 26 \\
\hline 2 & $\mathrm{Ru} / \mathrm{Co} / \mathrm{ZrO}_{2}-\mathrm{Na}$ & 0.09 & 1.4 & 19 & 64 & 35 \\
\hline 3 & $\mathrm{Ru} / \mathrm{Cr} / \mathrm{ZrO}_{2}-\mathrm{Na}$ & 0.05 & 0.74 & 11 & 69 & 32 \\
\hline 4 & $\mathrm{Ru} / \mathrm{Mn} / \mathrm{ZrO}_{2}-\mathrm{Na}$ & 0.10 & 1.5 & 21 & 67 & 33 \\
\hline 5 & $\mathrm{Ru} / \mathrm{V} / \mathrm{ZrO}_{2}-\mathrm{Na}$ & 0.07 & 0.84 & 18 & 57 & 26 \\
\hline 6 & $\mathrm{Ru} / \mathrm{Fe} / \mathrm{ZrO}_{2}-\mathrm{Na}$ & 0.11 & 1.8 & 24 & 68 & 38 \\
\hline 7 & $\mathrm{Ru} / \mathrm{Fe} / \mathrm{ZrO}_{2}-\mathrm{K}$ & 0.10 & 1.6 & 18 & 68 & 38 \\
\hline 8 & $\mathrm{Ru} / \mathrm{Fe} / \mathrm{ZrO}_{2}-\mathrm{Cs}$ & 0.10 & 1.6 & 24 & 53 & 23 \\
\hline 9 & $\mathrm{Ru} / \mathrm{Fe} / \mathrm{ZrO}_{2}-\mathrm{Ca}$ & $<0.01$ & 0.05 & 1.1 & 55 & $12^{\mathrm{d})}$ \\
\hline 10 & $\mathrm{Ru} / \mathrm{Fe} / \mathrm{ZrO}_{2}-\mathrm{Sr}$ & $<0.01$ & 0.34 & 6.0 & 63 & 27 \\
\hline 11 & $\mathrm{Ru} / \mathrm{Fe} / \mathrm{ZrO}_{2}-\mathrm{Ba}$ & 0.04 & 0.59 & 10 & 60 & 25 \\
\hline 12 & $\mathrm{Ru} / \mathrm{ZrO}_{2}-\mathrm{Na}^{\mathrm{e})}$ & 0.11 & 1.8 & 24 & 69 & 36 \\
\hline
\end{tabular}

a) $\mathrm{Na}, \mathrm{K}$, etc. indicate that the precipitant is $\mathrm{NaOH}, \mathrm{KOH}$, etc.

b) Initial rate is calculated by the first derivative at $t=0$ of the function obtained by fitting the experimental data according to $[12,13]$.

c) Initial selectivity to cyclohexene is obtained by calculating the limit for $\mathrm{t} \rightarrow 0$ of the function obtained by fitting the experimental data according to $[12,13]$.

d) Values measured at final conversion after $4 \mathrm{~h}$ of reaction

e) data from ref. [10]

\section{Relation between hydrogen chemisorption and activity}

Hydrogen chemisorption obtained by the double isotherm method gives the measure of both strongly and weakly bonded hydrogen. It is accepted that the strongly chemisorbed hydrogen is a direct measure of the exposed atoms (or of the dispersion), and that the weakly adsorbed one represents highly unsaturated sites which stabilize poly-hydride moieties and the physisorbed hydrogen [17, 20, 21]. We found that hydrogen physisorption at $373 \mathrm{~K}$ and 180 Torr is negligible. Thus, weakly adsorbed hydrogen is an actual measure of how the surface stabilizes a hydride-like complex which could affect catalyst activity and selectivity [20,21]. 


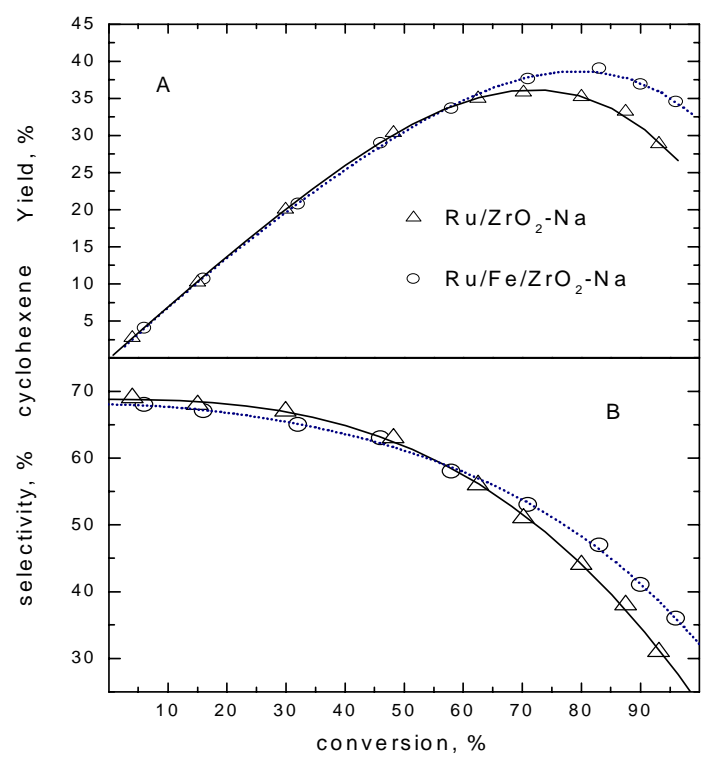

Fig. 1. Effect of Fe on selectivity and yield of cyclohexene $v s$ conversion: comparison of $\mathrm{Ru} / \mathrm{ZrO}_{2}-\mathrm{Na}$ and $\mathrm{Ru} / \mathrm{Fe} / \mathrm{ZrO}_{2}-\mathrm{Na}$ catalysts

Table 2

Hydrogen chemisorption on $\mathrm{Ru}-\mathrm{M}_{\mathrm{x}} \mathrm{O}_{\mathrm{y}} / \mathrm{ZrO}_{2}$ catalysts

\begin{tabular}{|c|c|c|c|c|c|c|c|}
\hline Entry & Catalyst & $\begin{array}{l}\mathrm{Ru} \\
(\%)\end{array}$ & $\begin{array}{c}\mathrm{H}_{2} \text { str. ads. } \\
(100 \text { Torr } \\
\left.\mathrm{mL}_{\mathrm{g}_{\text {cat }}}{ }^{-}\right)\end{array}$ & $\begin{array}{c}\mathrm{H}_{2} \text { wk. ads. } \\
(100 \text { Torr } \\
\left.\mathrm{mL} \mathrm{g}_{\mathrm{cat}}^{-1}\right)\end{array}$ & $\begin{array}{c}\mathrm{r}_{0} \mathrm{H}_{2} \\
\left(10^{2} \mathrm{~mol} \mathrm{~L}^{-1}\right. \\
\left.\mathrm{s}^{-1} \mathrm{~g}_{\mathrm{Ru}}^{-1}\right)\end{array}$ & $\begin{array}{c}\text { Initial } \\
\text { sel. } \\
(\%)\end{array}$ & $\begin{array}{l}\text { Max } \\
\text { yield } \\
(\%)\end{array}$ \\
\hline 1 & $\mathrm{Ru} / \mathrm{Ni} / \mathrm{ZrO}_{2}-\mathrm{Na}$ & 39.4 & 1.89 & 3.52 & 18 & 57 & 26 \\
\hline 2 & $\mathrm{Ru} / \mathrm{Co} / \mathrm{ZrO}_{2}-\mathrm{Na}$ & 40.1 & 1.15 & 3.77 & 19 & 64 & 35 \\
\hline 3 & $\mathrm{Ru} / \mathrm{Cr} / \mathrm{ZrO}_{2}-\mathrm{Na}$ & 34.5 & 2.02 & 2.22 & 11 & 69 & 32 \\
\hline 4 & $\mathrm{Ru} / \mathrm{Mn} / \mathrm{ZrO}_{2}-\mathrm{Na}$ & 37.0 & 1.94 & 3.38 & 21 & 67 & 33 \\
\hline 5 & $\mathrm{Ru} / \mathrm{V} / \mathrm{ZrO}_{2}-\mathrm{Na}$ & 27.8 & 1.36 & 2.28 & 18 & 57 & 26 \\
\hline 6 & $\mathrm{Ru} / \mathrm{Fe} / \mathrm{ZrO}_{2}-\mathrm{Na}$ & 38.6 & 1.33 & 3.01 & 24 & 68 & 38 \\
\hline 7 & $\mathrm{Ru} / \mathrm{Fe} / \mathrm{ZrO}_{2}-\mathrm{K}$ & 45.1 & 1.12 & 2.38 & 18 & 68 & 38 \\
\hline 8 & $\mathrm{Ru} / \mathrm{Fe} / \mathrm{ZrO}_{2}-\mathrm{Cs}$ & 35.7 & 1.69 & 3.49 & 24 & 53 & 23 \\
\hline 9 & $\mathrm{Ru} / \mathrm{Fe} / \mathrm{ZrO}_{2}-\mathrm{Ca}$ & 21.0 & 1.54 & 2.08 & 1.1 & 55 & $12^{\mathrm{a}}$ \\
\hline 10 & $\mathrm{Ru} / \mathrm{Fe} / \mathrm{ZrO}_{2}-\mathrm{Sr}$ & 29.5 & 0.74 & 2.54 & 6.0 & 63 & 27 \\
\hline 11 & $\mathrm{Ru} / \mathrm{Fe} / \mathrm{ZrO}_{2}-\mathrm{Ba}$ & 29.9 & 0.86 & 3.02 & 10 & 60 & 25 \\
\hline
\end{tabular}

a) values measured at final conversion after $4 \mathrm{~h}$ of reaction 


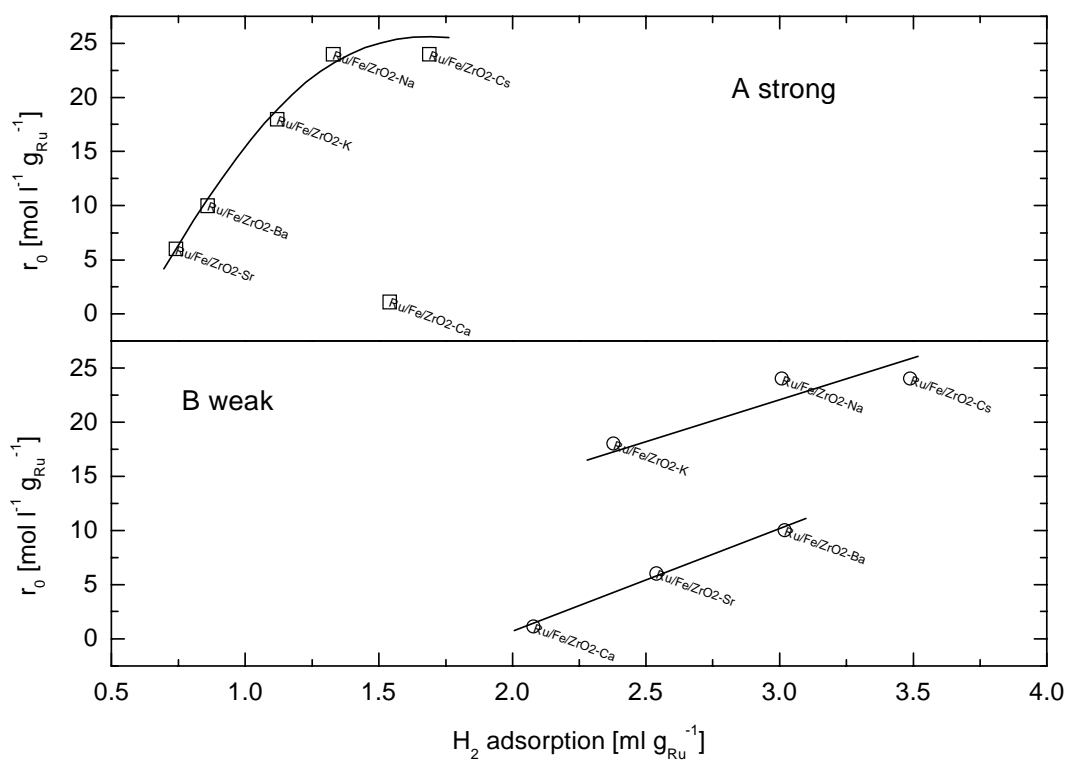

Fig. 2. Influence of weak adsorption of hydrogen on the initial rate of reactions of $\mathrm{Ru}-\mathrm{Fe}_{2} \mathrm{O}_{3} / \mathrm{ZrO}_{2}$ catalysts

In Table 2 weak and strong hydrogen chemisorptions are reported. No direct relationship has been observed between strong chemisorbed hydrogen (or dispersion) and catalyst activity (entry 1-11), thus, it is likely that catalyst activity is a specific surface effect of each metal oxide on the active $\mathrm{Ru}$ particles. Entries 6-11 show the influence of the base employed for the precipitation of the $\mathrm{Ru}$ precursor on the support for $\mathrm{Fe}$ promoted catalysts. Except for entry $9\left(\mathrm{Ru} / \mathrm{Fe} / \mathrm{ZrO}_{2}-\mathrm{Ca}\right)$, catalyst activity increases with metal dispersion increasing, suggesting a specific effect of $\mathrm{Fe}_{2} \mathrm{O}_{3}$ (see Fig. 2A). Furthermore, a trend can be established between the weakly chemisorbed hydrogen and the initial reaction rate among the same group of bases, as reported in Fig. 2B, which shows that the increase of the initial rate follows the reversible hydrogen chemisorption increasing. It is likely that weakly hydrogen adsorption occurs only on the available sites after partially covering by water, benzene, cyclohexene and cyclohexane. 


\section{REFERENCES}

1. Y. Kunihiko, O. Hideaki, K. Issei: Eur. Pat. 552809 A1 to Asahi chem. Co. (1993).

2. W. Doering, P. Polanek: Eur. Pat. 554,765 to BASF AG (1995).

3. J. Gaube, F. Doerbert: U.S. Pat. 6,344,593 to BASF AG (2002).

4. H. Nagahara, M. Konishi: U. S. Pat. 4,734,536 to Asahi Kasei Kogyo Kabushiki Kaisha (1988).

5. J. Struijk, M. d'Agremont, W.J. M. Lucas-de Regt, J.J.F. Scholten: Appl. Catal., A, 83, 263 (1992).

6. W.L. Drinkart: NL Pat. 7205832 to Dupont de Nemours (1972).

7. S. Niwa, F. Mizukami, M. Kuno, K. Takeshita, H. Nakamura, T. Tsuchiya, K. Shimizu, J. Imamura: J. Mol. Catal., 34, 247 (1986).

8. S. Xie, M. Qiao, H. Li, W. Wang, J. Deng: Appl. Catal., A , 176, 129 (1999).

9. J. Gaube, F. Doerbert: Chem. Eng. Science, 51, 2873 (1996).

10. L. Ronchin, L. Toniolo: React. Kinet. Catal. Lett., 78, 281 (2003).

11. L. Ronchin, L. Toniolo: Catal. Today, 66, 363 (2001).

12. L. Ronchin, L. Toniolo: Appl. Catal. A, 208, 77 (2001).

13. L. Ronchin, L. Toniolo: Catal. Today, 48, 255 (1999).

14. G.W. Roberts: in P.N. Rylander, H. Greenfield (Editors): Catalysis in Organic Synthesis, p. 1. Academic Press, New York 1976.

15. J.J. Carberry: Catalysis Science and Technology, 8, 131 (1987).

16. S.J. Greg, K.S. W. Sing in: Adsorption Surface Area and Porosity. II edition. Academic Press 1982.

17. R.A. Dalla Betta: J. Catal., 34, 57 (1974).

18. J.H. Synfelt, Y.L. Lam, L. Cusumano, E.A. Barnet: J. Catal., 42, 227 (1976).

19. J.A. Don, J.J. F. Scholten: Appl. Catal., 41, 146 (1981).

20. D.O. Uner, M. Prusky, B.C. Gerstein, T.S. King: J. Catal., 146, 53 (1994).

21. K. Lu, B.J. Tatarchuk: J. Catal., 106, 166 (1987). 